\title{
Effects of Mangaba (Hancornia speciosa) Fruit Extract Adsorbed onto PEG Microspheres in MCF-7 Breast Cancer Cells Co-Cultured with Blood Cells
}

\author{
Renata Lázara de Araújo ${ }^{1}$, Suiane Savazzi ${ }^{1}$, Mahmi Fujimori², Alessandra Lima \\ Deluque $^{2}$, Eduardo Luzia Honório-França ${ }^{1,2}$, Paula Becker Pertuzatti Konda ${ }^{1}$, \\ Adenilda Cristina Honório-França ${ }^{1,2 *}$
}

\begin{abstract}
Objective: To evaluate the antitumor effects of polyethylene glycol (PEG) microspheres with adsorbed Hancornia speciosa ethanolic extract (HSEE) on blood mononuclear (MN) cells co-cultured with MCF-7 breast cancer cells. Methods: PEG microspheres were adsorbed with HSEE and examined by flow cytometry and fluorescence microscopy. MCF-7 and MN cells obtained from volunteer donors were pre-incubated alone or co-cultured (MN and MCF-7 cells) for $24 \mathrm{~h}$ with or without HSEE, PEG microspheres or PEG adsorbed with HSEE (PEG-HSEE). Cell viability, superoxide release and superoxide dismutase were determined. Results: Fluorescence microscopy showed that PEG microspheres were able to absorb HSEE throughout their surface. Irrespective of the treatment, the viability index of MN cells, MCF-7 and their co-culture was not affected. Superoxide release increased in co-cultured cells treated with HSEE, adsorbed or not onto PEG microspheres. In co-cultured cells, SOD levels in culture supernatant increased in the treatment with HSEE, adsorbed onto PEG microspheres or not. Conclusion: HSEE has direct effects on MN cells co-cultured with MCF-7 cells. The results suggest the benefits of Hancornia speciosa fruit consumption by women at risk of breast cancer. In addition, because PEG-HSEE maintained oxidative balance in co-cultured cells, it is a promising alternative for the treatment of tumor cells.
\end{abstract}

Keywords: Microspheres- antioxidant activity- Brazilian fruit- biomaterial- cancer

Asian Pac J Cancer Prev, 20 (7), 1995-2001

\section{Introduction}

Cancer is one of the most serious public health problems worldwide (Siegel et al., 2017). Breast cancer, in particular, is the most frequent among women, showing elevated incidence and a high mortality rate (Jemal et al., 2011).

In the search for cancer preventing drugs and treatments with few or no side effects, numerous studies have investigated medicinal plants (Greenwell and Rahman, 2015) combined with modified drug delivery systems such as a polymer matrix (Tran et al., 2011). The use of polyethylene glycol (PEG) stands out for its valuable pharmacological properties that allow modulated and prolonged drug action (Reinaque et al., 2012). PEG has been used as a carrier of different microparticulate drugs delivered in oral and parenteral systems developed to treat a number of diseases, including cancer (Gulapalliand-Mazitelli, 2015).

The combination of medicinal plants and polymer matrices raises the possibility of developing new drugs and treatments. For instance, a recent study found that a mixture of plant extracts adsorbed onto PEG microspheres have antitumor effects, and the authors suggested that the participation of blood mononuclear (MN) cells is important in achieving that result (Ribeiro et al., 2018).

The Brazilian Cerrado is the second largest biome in South America and the richest tropical biome in the world in terms of biodiversity (Sano et al., 2010). Being a rich source of bioactive compounds, fruits from the Cerrado are a promising alternative for developing medicines (Bailão et al., 2015). That is the case of the fruits of mangaba, Hancornia speciosa, a plant from the Apocynaceae family that is typical from the Brazilian Cerrado. Mangaba fruits contain a large amount of ascorbic acid (Carnelossi et al., 2004), and therefore they have great potential to sequester free radicals (Rufino et al., 2010). Despite exhibiting these properties, the action of $H$. speciosa fruit on tumors has yet to be studied.

The ethanolic extract of the $H$. speciosa fruit exhibits

${ }^{1}$ Post Graduate Program in Material Science, ${ }^{2}$ Institute of Biological and Health Science, Federal University of Mato Grosso, Barra do Garças, MT, Brazil. *For Correspondence: adenildachf@terra.com.br 
cytotoxic activity, and the pulp has an antimutagenic effect on the bone marrow and colon tissue of mice (Lima et al., 2015). Other beneficial effects have been reported such as protection against cardiovascular diseases due to its antioxidant components (Melo et al., 2006; Quideau et al., 2011), reinforcing its potential as a medicinal plant.

Strategies to eliminate tumor cells include unbalancing their oxidative metabolism (Ray et al., 2012) and strengthening the antitumor effects of bioactive compounds using polymer-based drug delivery systems (França et al., 2016; Honorio-França et al., 2016; Silva et al., 2018). Given that H. speciosa fruit contains bioactive components with antioxidant activity that likely modulate the oxidative stress of tumor cells, the present study produced PEG microspheres adsorbed with $H$. speciosa ethanolic extract (HSEE) and tested their effects on MCF-7 human breast cancer cells in co-culture with blood MN cells.

\section{Materials and Methods}

\section{Ethanolic extract preparation (EE)}

Hancornia.speciosa fruits were collected by R.L. Araújo in November 2016, on the outskirts of Barra do Garças, Mato Grosso (MT) state, Brazil (1553'24”S, $52^{\circ} 15^{\prime} 24$ "W; $318 \mathrm{~m}$ altitude). An H. speciosa specimen was deposited in the herbarium of the Federal University of Mato Grosso, Pontal do Araguaia, MT, Brazil. After ripening, the fruits were washed in water, had the seeds removed and were then macerated with ethyl alcohol (1:5, $\mathrm{m} . \mathrm{v}-1)$ in an amber glass flask, left to stand for 15 days at room temperature $\left(25^{\circ} \mathrm{C}\right)$, and shaken once a day. The liquid was then filtered using an analytical funnel, distilled in a rotary evaporator (Fisatom-801) and incubated at $45^{\circ} \mathrm{C}$ (BioPar-527) to remove the alcohol. The H. speciosa ethanolicextract (HSEE) obtained was adjusted to a final concentration of $100 \mathrm{ng} \cdot \mathrm{mL}-1$.

\section{Polyethylene glycol (PEG) microsphere preparation}

Polyethylene glycol (PEG) 6,000 was used to produce the PEG microspheres applying Scott et al.,'s (2010) protocol, modified by Scherer et al., (2011). Briefly, $20 \mathrm{~g}$ of PEG 6,000 was resuspended in $100 \mathrm{~mL}$ of $2 \%$ sodium sulfate (in phosphate-buffered saline, PBS) and incubated at $37^{\circ} \mathrm{C}$ for $45 \mathrm{~min}$. After incubation, the PEG microspheres were diluted $3: 1$ in PBS, washed twice with PBSand centrifuged (500 x g, 5 min). The PEG microspheres were resuspended in PBS. Microphere formation was thermally induced by heating the solution to $95^{\circ} \mathrm{C}$ for $5 \mathrm{~min}$. For adsorption, PEG microspheres suspended in PBS were incubated with $100 \mathrm{ng}$ mL-1 HSEE at $37^{\circ} \mathrm{C}$ for $30 \mathrm{~min}$, as described by Reinaque et al., (2012). To determine loading efficiency, PEG microspheres adsorbed with HSEE (PEG-HSEE) or not were labeled with Dylight-488 fluorescent dye (Pierce Biotechnology, Rockford, USA; $10 \mu \mathrm{g} \mathrm{mL-1),} \mathrm{by} \mathrm{overnight} \mathrm{incubation} \mathrm{in}$ dimethylformamide at room temperature, at a 100:1 molar ratio of PEG:Dylight. The samples were then analyzed by fluorescence microscopy.

\section{PEG microsphere characterization by flow cytometry}

Immunofluorescence staining with phycoerythrin
(PE) (Sigma, St. Louis, USA) was used to compare the ability of PEG and polymethylmethacrylate microspheres (CaliBRITE - BD, San Jose, USA) to bind fluorescent markers. The PEG microspheres, adsorbed or not onto HSEE, were incubated with $5 \mu \mathrm{L}$ of $0.1 \mathrm{mg} \mathrm{mL}-1 \mathrm{PE}$ at $37^{\circ} \mathrm{C}$ for $30 \mathrm{~min}$. After incubation, the PEG microspheres were washed twice in PBS containing $5 \mathrm{mg}$ mL-1 BSA centrifuged $\left(500 \mathrm{x} \mathrm{g}\right.$ at $4^{\circ} \mathrm{C}$ for $\left.10 \mathrm{~min}\right)$ and analyzed by flow cytometry (FACS Calibur, BD, San Jose, USA). The size of the PEG microspheres, calculated by forward scattering (FSC), was compared to that of BD microspheres $(6 \mu \mathrm{m}$ CaliBRITE 3 Beads, BD Cat. No340486, San Jose, USA), bound or unbound to PE (Scherer el., 2011).

\section{Subjects}

The subjects consisted of 32 healthy men aged between 18 and 35 years, with no diagnosed diseases such as hypertension and diabetes, who abstained from drinking alcohol and smoking. A $15 \mathrm{~mL}$ blood sample was collected from each subject. The study was approved by the ethics committee of the Federal University of Mato Grosso, Araguaia Campus (CAAE Protocol Number: 1.415.375) and all the volunteers gave their written informed consent.

\section{Mononuclear (MN) cell isolation}

The blood samples were collected in heparinized (25 U.ml ${ }^{-1}$ ) tubes, and fractionated by Ficoll-Paque density gradient centrifugation (density 1.077 g. $\mathrm{L}^{-1}, 160 \mathrm{x}$ g for $30 \mathrm{~min}$ ) (Pharmacia, Upsala, Sweden). This procedure resulted in $98 \%$ pure mononuclear $(\mathrm{MN})$ phagocyte preparations, as analyzed morphologically by light microscopy. Purified MN phagocytes were resuspended independently in serum-free medium 199 to a final concentration of $2 \times 10^{6}$ cells $/ \mathrm{mL}$ (Honorio-França et al., 2013).

The MN cells obtained were pre-incubated with or without $50 \mu \mathrm{L}$ of $100 \mathrm{ng} \cdot \mathrm{mL}^{-1} \mathrm{HSEE}, 50 \mu \mathrm{L}$ of PEG microspheres or $50 \mu \mathrm{L}$ of $100 \mathrm{ng} \cdot \mathrm{mL}^{-1}$ PEG-HSEE. The cells were then resuspended in RPMI 1640 medium supplemented with 10\% fetal bovine serum (FBS - Sigma, St. Louis, MO, USA), penicillin (20 U.mL $\left.\mathrm{mL}^{-1}\right)$ and streptomycin $\left(20 \mu \mathrm{g} . \mathrm{mL}^{-1}\right)$ (Sigma, St. Louis, MO, USA) at $37^{\circ} \mathrm{C}$ for $24 \mathrm{~h}$, in a humidified atmosphere containing $5 \% \mathrm{CO}_{2}$. The $\mathrm{MN}$ cells were then washed twice and used in the assay.

\section{MCF-7 cell culture}

Subconfluent monolayers $(80 \%)$ of MCF-7 cells were treated with trypsin (Sigma, St. Louis, USA) at a concentration adjusted to $5 \times 10^{6}$ cells. $\mathrm{mL}^{-1}$. The trypsinized cells were pre-incubated for $24 \mathrm{~h}$ with or without $50 \mu \mathrm{L}$ 100 ng.mL-1 HSEE, $50 \mu \mathrm{L}$ of PEG microspheres or $50 \mu \mathrm{L}$ of 100 ng. $\mathrm{mL}^{-1}$ PEG-HSEE. The cells were then resuspended in RPMI 1640 medium supplemented with $10 \%$ fetal bovine serum (FBS) (Sigma, St. Louis, MO, USA), penicillin (20 U.mL $\left.\mathrm{mL}^{-1}\right)$ and streptomycin (20 $\mu \mathrm{g} . \mathrm{mL}^{-1}$ ) (Sigma, St. Louis, MO, USA) at $37^{\circ} \mathrm{C}$ for $24 \mathrm{~h}$ in a humidified atmosphere containing $5 \% \mathrm{CO}_{2}$. 
Co-culture of MNand MCF-7 cells

Cell co-culture systems incorporating $\mathrm{MN}$ and MCF-7 cells $\left(5 \times 10^{6}\right.$ cells. $\left.\mathrm{mL}^{-1}\right)$ were performed using the same protocol described by Ribeiro et al., (2018).

After the co-cultures were incubated, they were washed twice and used in the experiments. The cells were evaluated in suspension by flow cytometry because aliquid medium allows the suspended cells to flow one at a time.

\section{Cell Viability assay}

Cell viability was evaluated using the Bellinate-Pires (1989) acridine orange method modified by Honorio-França et al., (1997). Equal volumes of cell suspensions (MN, MCF-7 or their co-culture cells, treated or not with HSEE or PEG-HSEE) were mixed and incubated at $37^{\circ} \mathrm{C}$ for $3 \mathrm{~h}$ under continuous stirring. The cells were resuspended in serum-free 199 medium and centrifuged. The supernatant was discarded and the sedimentstained with $200 \mu \mathrm{L}$ acridine orange (Sigma, St Louis, USA; 14.4 g. $\mathrm{L}^{-1}$ ) for $1 \mathrm{~min}$. The sediment was resuspended in cold 199 medium, washed twice and observed under fluorescence microscopy at 400x and $1.000 \mathrm{x}$ magnification.

The viability index was calculated by counting the number of orange-stained (dead) and green-stained (alive) cells (França et al., 2011) in 100-cell pool samples. The experiments were performed in duplicate.

\section{Superoxide anion release}

Superoxide release was determined by cytochrome C (Sigma, St Louis, USA) reduction (Honorio-França et al., 1997). Briefly, MN, MCF-7and co-cultured MN-MCF-7 cells, treated or not with HSEE or PEG-HSEE, were mixed and incubated for $24 \mathrm{~h}$ and centrifuged (160 x $\mathrm{g}, 10 \mathrm{~min})$. The cells were then resuspended in PBS containing $2.6 \mathrm{mM} \mathrm{CaCl}_{2}, 2 \mathrm{mM} \mathrm{MgCl}$, and cytochrome C. The suspensions $(100 \mu \mathrm{L})$ were incubated at $37^{\circ} \mathrm{C}$ for $1 \mathrm{~h}$ on culture plates. A control group was used to test the spontaneous release of untreated cells. The reaction rates were measured by absorbance at $550 \mathrm{~nm}$, and the resultsexpressed as nmol. $\mathrm{O}^{2-}$. The experiments were performed in duplicate.

\section{CuZn-superoxide dismutase determination (CuZn-SOD - E.C.1.15.1.1)}

The CuZn-SOD enzyme was determined in the supernatant of the culture of MN, MCF-7or co-cultured MN and MCF-7 cells, treated or not with HSEE or PEG-HSEE, using the nitroblue tetrazolium (NBT) reduction method (Sigma, St Louis, USA). Individual 0.5 $\mathrm{mL}$ aliquots of supernatant (MN, MCF-7or co-cultured cells) were placed in glass tubes. Another tube was prepared with $0.5 \mathrm{~mL}$ of a standard hydroalcoholic solution. Next, $0.5 \mathrm{~mL}$ of chloroform-ethanol solution (1:1 ratio) and $0.5 \mathrm{~mL}$ of reactive mixture (NBT increased by EDTA) were added to the tubes. The experimental and standard solutions received $2.0 \mathrm{~mL}$ of carbonate buffer, and the pHincreased to 10.2 after the addition of hydroxylamine. The tubes were left undisturbed at room temperature for $15 \mathrm{~min}$ and then read at $560 \mathrm{~nm}$. Superoxide dismutase was calculated as follows:
$\mathrm{CuZn}-\mathrm{SOD}=(\mathrm{Ab}$ standard $-\mathrm{Ab}$ sample $/ \mathrm{Ab}$ standard $)$ $\mathrm{x} 100=\%$ reduction of NBT $/ \mathrm{CuZn--SOD}$.

The results were expressed in international units (IU) of CuZn-SOD.

\section{Statistical analysis}

Analysis of variance (ANOVA) with the F-test followed byTukey's multiple comparison test were used to evaluate cell viability, superoxide release and superoxide dismutase of MN, MCF-7or co-cultured MN-MCF-7 cells, treated or not with HSEE or PEG-HSEE. Statistical significance was considered at $\mathrm{p}<0.05$.

\section{Results}

\section{Characterization of PEG microspheres}

Examination of the PEG microspheres under fluorescence microscopy showed that they retained the spherical structure with no deformities (Figure 1A). The images also showed that the microspheres absorbed HSEE on their surface PEG (Figure 1B).

Figure 2A compares the fluorescence intensity of PEG microspheres to that of PEG microspheres adsorbed with HSEE and standard BD microspheres. After HSEE adsorption, the geometric mean fluorescence intensity of the PEG microspheres changed and their size increased (Figure 2B).

\section{Cell Viabilty}

The viability of MN, MCF-7 and their co-culture cells

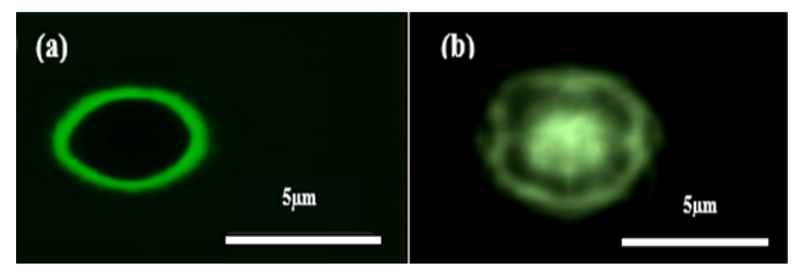

Figure 1. Fluorescence Microscopy Image of Polyethylene Glycol (PEG) Microspheres Stained with Dylight-488 (100x - panels - A). PEG microsphere (Figure 1A); PEG microsphere adsorbed to $100 \mathrm{ng} \cdot \mathrm{mL}^{-1}$ H. speciosa ethanolic extract (Figure 1B). Comparable results of 5 replications.

Table 1. Viability of MN Cells, MCF-7 Cells and co-cultured $\mathrm{MN}$ and MCF-7 Cells Exposed to H. speciosa Ethanolic Extract, PBS, PEG Microspheres or PEG Adsorbed with HSEE (PEG-HSEE).

\begin{tabular}{lccc}
\hline & MN Phagocytes & MCF- Cells & Co-culture \\
\hline PBS & $96 \pm 3.5$ & $96 \pm 1.4$ & $96 \pm 1.9$ \\
PEG & $296 \pm 2.6$ & $92 \pm 3.5$ & $96 \pm 2.9$ \\
HSEE & $96 \pm 1.5$ & $96 \pm 3.8$ & $99 \pm 3.0$ \\
PEG-HSEE & $99 \pm 2.6$ & $95 \pm 4.0$ & $97 \pm 3.6$ \\
\hline
\end{tabular}

Note: The results are expressed as mean $\pm \mathrm{SD}(\mathrm{N}=6)$. Phosphate buffered saline (PBS); Polyethylene glycol (PEG) microspheres; H. speciosa ethanolic extract (HSEE); H. speciosa ethanolic extract adsorbed onto PEG microspheres (PEG-HSEE). * $\mathrm{p}<0.05$, comparing treated to non-treated cells (PBS); $+\mathrm{P}<0.05$, comparing $\mathrm{PEG}$, HSEEand PEG-HSEE treatments; \#P $<0.05$, comparing MN, MCF-7 and co-cultured MN and MCF-7 cells. 
A

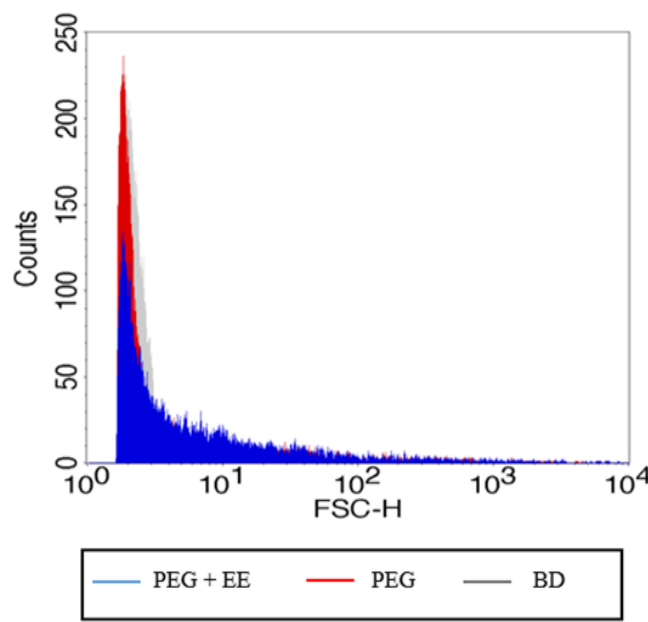

B

\begin{tabular}{|l|l|}
\hline Microspheres & Size $(\mu \mathrm{m})$ \\
\hline Polymethyl methacrylate(BD) & $6.0 \pm 0.21$ \\
\hline Polyethylene Glicol (PEG) & $6.2 \pm 0.31$ \\
\hline Polyethylene Glicol (PEG) + HSEE(100 ng.mL-1) & $6.6 \pm 0.30$ \\
\hline
\end{tabular}

Figure 2. PEG Microspheres Stained with Phycoerythrin (PE) and Standard PE-Labeled Polymethyl Methacrylate Microsphere (BD Microsphere, Becton Dickinson, San Jose, USA), with Fluorescence Intensity and Size Determined by Flow Cytometry (FACScalibur, Becton Dickinson, San Jose, USA). Microsphere size according to forward scatter (A); geometric mean of the microsphere adsorbed with 100 ng.mL-1 H. speciosa ethanolic extract (B).

was not affected by incubation with HSEE (adsorbed or not onto PEG microspheres) and was similar to that obtained after incubation with culture medium alone. The cell viability index values were above 90\% (Table 1).

\section{Effects of PEG-HSEE on Superoxide Release}

Superoxide release by MN and MCF-7 cells did not change after treatment with HSEE alone or PEG-HSEE (Figures 3A and 3B), but did increase in co-cultured MN and MCF-7 cells treated withHSEE and PEG-HSEE (Figure 3C).

\section{Effects of PEG-HSEE on Superoxide Dismutase (Cu-Zn-SOD)}

In MN cells, the superoxide dismutase (SOD) levels in culture supernatant were lower in the HSEE treatment and higher in PEG-HSEE. MCF-7 cells generally showed the highest SOD levels, but were lower when treated with HSEE. In co-cultured cells, SOD levels in culture supernatant were higher in the PEG-HSEE treatment (Table 2). MCF-7 cells and co-cultured cells showed the highest SOD levels, irrespective of HSEE treatment (Table 2).

\section{Discussion}

The combination between plants and polymer matrices raised the possibility of developing new drugs to treat or prevent a number of diseases, including cancer. In
Table 2. Superoxide Dismutase (SOD) Levels in the Culture Supernatant of MN Cells, MCF-7 Cells and Co-Cultured MN and MCF-7 Cells Exposed to PBS, H. speciosa ethanolic extract, PEG microspheres or PEG adsorbed with HSEE (PEG-HSEE).

\begin{tabular}{lccc}
\hline & MN Phagocytes & MCF- Cells & Co-culture \\
\hline PBS & $14.3 \pm 1.0$ & $77.9 \pm 3.8^{\#}$ & $75.5 \pm 5.1^{\#}$ \\
PEG & $17.4 \pm .1 .0$ & $69.5 \pm 6.4^{* \#}$ & $64.1 \pm 6.8^{\#}$ \\
HSEE & $6.28 \pm 0.6^{*}$ & $77.6 \pm 1.5^{* \#}$ & $86.4 \pm 6.6^{* \#}$ \\
PEG-HSEE & $27.0 \pm 1.1^{*}$ & $86.5 \pm 8.4^{\#}$ & $85.0 \pm 9.8^{* \#}$ \\
\hline
\end{tabular}

Note: The results are expressed as mean $\pm \mathrm{SD}(\mathrm{N}=6)$. Phosphate buffered saline (PBS); polyethylene glycol (PEG) microspheres; $H$. speciosa ethanolic extract (HSEE); H. speciosa ethanolic extract adsorbed onto PEG microspheres (PEG-HSEE). ${ }^{*} \mathrm{p}<0.05$, comparing PEG, HSEE and PEG- HSEE treatments for a same type of cell; \#P $<0.05$, comparing MN, MCF- 7 and co-cultured MN and MCF-7 cells within a same treatment.

the present study, we produced PEG microspheres adsorbed with ethanolic extract of Hancornia speciosa (PEG-HSEE) and tested their effects on the oxidative stress of blood MN phagocytes co-cultured with MCF-7 human breast cancer cells. HSEE exhibited activity against MCF-7 cells. It activated blood MN cells, as indicated by the increase in superoxide release and SOD levels, determining a balance of the mechanisms involved in cellular oxidative stress.

PEG is a copolymer used in the clinical administration of drugs due to its adsorption capacity (Gang and Si-Shen, 2003). In the present study, the interaction of PEG microspheres with blood phagocytes co-cultured or not with MCF-7 cells did not affect the viability of the cells tested, suggesting that HSEE is non-toxic. Other plant extracts have shown a similar non-toxic response (Scherer et al., 2011; Reinaque et al., 2012; Cortês et al., 2013; Ribeiro et al., 2018). In fact, plant extracts can activate the immune system to help in the treatment of diseases without compromising the viability of the immune cells involved (Hasani-Ranjbar et al., 2008).

Superoxide release was higher in MN phagocytes co-cultured with MCF-7 cells and treated with HSEE, adsorbed or not onto PEG microspheres, suggesting the stimulatory effect of the extract on MN cells.

The production of free radicals by MN cells is an important body defense mechanism (França et al., 2011). The increase in intracellular reactive oxygen species (ROS) levels is a form of inducing cell death. ROS are highly aggressive products of biological reactions that are damaging to the cells. It is important to highlight that ROS are not cellular waste products, but rather signaling molecules that are essential for the body to function properly (Angelova et al., 2016). These molecules are involved in a number of actions, including immune reactions, inflammation, transcription factor regulation and longevity beyond peroxidation of cellular lipids, proteins, carbohydrates and DNA. In the present study, the increase in superoxide release in co-culture of $\mathrm{MN}$ and MCF-7 cells with the use of HSEE may be an important mechanism for preventing and treating breast cancer.

The balance between pro-oxidant and antioxidant mechanisms is extremely important because they can 
A
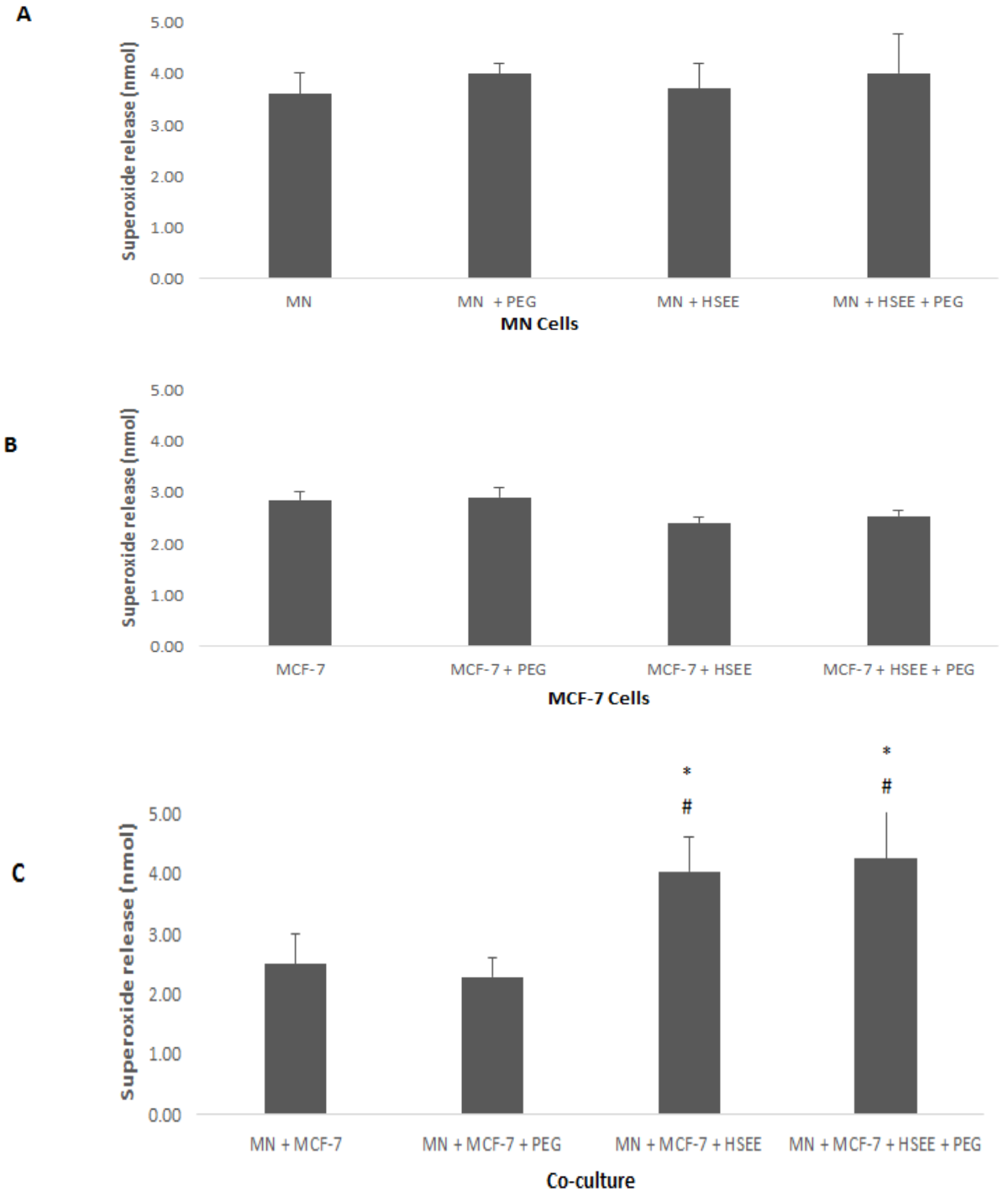

Figure 3. Superoxide Release by Blood MN(A), MCF-7(B) and Co-Cultured MN and MCF-7 Cells (C) Incubated with PBS, PEG, H. speciosa Ethanolic Extract (HSEE) Alone or Adsorbed to PEG Microspheres (HSEE-PEG) after 24-h Culture. Data are expressed as mean $\pm \mathrm{SD}$. *difference between the treatments PEG, HSEE and PEG- HSEE for a same cell type $(\mathrm{P}<0.05)$; \# difference between MCF-7and co-cultured MN and MCF-7 cells within a same treatment $(\mathrm{P}<0.05)$.

trigger ROS-induced apoptosis (Maritim et al., 2003). The increase in SOD observed in the MCF-7 cells under study, however, was not associated with an increase in superoxide release. In general, antioxidant mechanisms protect cells, but paradoxically they can induce the death of tumor cells (Skrzydlewska et al., 2001).

Changes in the oxidative metabolism of tumor cells may unbalance the production of antioxidant enzymes such as SOD (Sriram et al., 2008). In addition, higher SOD activity after the use of antioxidants explains the decrease in superoxide levels (Mannerlig et al., 2010). An interesting result is the reduction in SOD levels with HSEE treatment, which was possibly a compensatory response to the imbalance between pro-oxidant and antioxidant mechanisms and a form of preventing tumor cell defense against antioxidants.

One noteworthy aspect is that SOD in cancer has a dual role: while its high activity prevents the development of a favorable environment for inflammatory cancer (Becuwe et al., 2014), it may also enhance the invasive potential of cancer once the disease has established itself ( $\mathrm{Li}$ et al., 2015). As such, the introduction of $H$. speciosa fruit in the diet of women at risk for developing breast cancer may be a feasible strategy to prevent this type of tumor.

In co-cultured MN and MCF-7 cells, PEG-HSEE treatment increased superoxide release and produced the highest SOD levels. The result suggests that the antioxidant system of MN cells was maintained as was oxidative balance, which may contribute to controlling tumor cells, since it prevents an inflammatory environment capable of eliminating other body cells (Kim et al., 2007). Moreover, SOD has the important role of converting $\mathrm{O}_{2}$ - into hydrogen peroxide ( $\left.\mathrm{H} 2 \mathrm{O} 2\right)$, which in the absence of transition metals, shows low reactivity between organic molecules (Kim et al., 2015).

In conclusion, $H$. speciosa fruit extract caused direct effects on the co-culture of MN and MCF-7 cells. The results suggest that fruit consumption should be strongly 
encouraged for women at risk for breast cancer. In addition, given that the oxidative balance obtained in co-cultured cells treated with the fruit extract adsorbed onto PEG microspheres was maintained, it can potentially be used to combat tumor cells.

\section{Acknowledgements}

To Coordination for the Improvement of Higher Level Personnel (CAPES, Brazil) and National Council for Scientific and Technological Development (CNPq, Brazil, nos: 447218/2014-0 and 305725/2018-1), for providing grants to the study.

\section{Conflict of Interests}

The authors declare no conflict of interest and nonfinancial competing interests regarding the publication of this article.

\section{References}

Angelova PR, Abramov AY (2016). Functional role of mitochondrial reactive oxygen species in physiology. Free Radic Biol Med, 100, 81-5.

Bailão EF, Devilla IA, Conceição EC, Borges LL (2015). Bioactive compounds found in brazilian cerrado fruits. Int J Mol Sci, 16, 23760-83.

Becuwe P, Ennen M, Klotz R, Barbieux C, Grandemange S (2014). Manganese superoxide dismutase in breast cancer: from molecular mechanisms of gene regulation to biological and clinical significance. Free Radic Biol Med, 77, 139-51.

Bellinate-Pires R (1989). Evaluation of fluorochrome assay for assessing the bactericidal activity of neutrophils in human phagocyte dysfunctions. J Immunol Methods, 119, 189.

Carnelossi MAG, Toledo WFF, Souza DCL, et al (2004). Postharvest conservation of mangaba (Hancorniaspeciosa Gomes). Ciêncagrotec, 28, 1119-25.

Côrtes MA, França EL, Reinaque APB, Scherer EF, Honorio-França AC (2013). Immunomodulation of human blood phagocytes by Strychnos pseudoquina ST. HILL adsorbed to Polyethylene glycol (PEG). Polímeros, 23, 402-9.

França EL, Honorio-França AC, Fernandes RT, et al (2016). The effect of melatonina adsorbed to polyethylene glycol microspheres on the survival of MCF-7 cells. Neuroimunomodulation, 23, 27-32.

França EL, Morceli G, Fagundes DL, et al (2011). Secretory IgA Fc $\alpha$ receptor interaction modulating phagocytosis and microbicidal activity by phagocytes in human colostrum of diabetics. APMIS, 119, 719-10.

Gang R, Si-Shen F (2003). Preparation and characterization of poly(lacticacid)-poly(ethyleneglycol)-poly(lacticacid) (PLA-PEG-PLA) microspheres for controlled release of paclitaxel. Biomaterials, 24, 5037-33.

Greenwell M, Rahman P (2015). Medicinal plants: their use in anticancer treatment. Eur PMC, 6, 4103-12.

Gulapalli RP, Mazzitelli CL (2015). Polyethylene glycols in oral and parenteral formulations- A critical review. Int $J$ Pharm, 496, 219-39.

Hasani-Ranjbar S, Larijani B, Abdollah MA (2008). Systematic review of Iranian medicinal plants useful in diabetes mellitus. Arch Med Sci, 4, 285-92.

Honorio-França AC, Carvalho MP, Isaac L, Trabulsi LR, Carneiro-Sampaio MM (1997). Colostral mononuclear phagocytes are able to kill enteropathogenicEscherichia coli opsonized with colostral IgA. Scand J Immunol, 46, 59-66.

Honorio-França AC, Hara CCP, Ormonde JVS, Nunes GT, França EL (2013). Human colostrum melatonin exhibits a day-night variation and modulates the activity of colostral phagocytes. J Appl Biomed, 111, 153-62.

Honorio-França AC, Nunes GT, Fagundes DLG, et al (2016). Intracellular calcium is a target of modulation of apoptosis in MCF-7 cells in the presence of IgA adsorbed to polyethylene glycol. Onco Targets Ther, 3, 617-26.

Jemal A, Bray F, Center MM, et al (2011). Global cancer statistics. CA Cancer J Clin, 61, 69-90.

Kim DW, Hong GH, Lee HH (2007). Effect of colloidal silver against the cytotoxicity of hydrogen peroxide and naphthazarin on primary cultured cortical astrocytes. Neuroscience, 117, 387.

Kim GH, Kim JE, Rhie SJ, Yoon S (2015). The role of oxidative stress in neurodegenerative diseases. Exp Neurol, 24, 325-40.

Li W, Cao L, Han L, Xu Q, Ma Q (2015). Superoxide dismutase promotes the epithelial-mesenchymal transition of pancreatic cancer cells via activation of the $\mathrm{H} 2 \mathrm{O} 2 / \mathrm{ERK} / \mathrm{NF}-\kappa \mathrm{B}$ axis. Int J Oncol, 46, 2613-20.

Lima JP, Fante CA, Pires CRF, et al (2015). The antioxidative potential and volatile constituents of mangaba fruit over the storage period. Sci Hortic, 194, 1-6.

Mannerlig AC, Simkó M, Mild KH, Mattsson MO (2010). Effects of $50-\mathrm{Hz}$ magnetic field exposure in superoxide radical anion formation and HSP70 induction in human K562 cells. Radiat Environ Biophys, 49, 731-41.

Maritim AC, Sanders RA, Watkins JB (2003). Diabetes, oxidative stress, and antioxidants: a review. J Biochem $\mathrm{Mol}$ Toxicol, 17, 24-38.

Melo EA, Lima VLA. G, Maciel MIS (2006). Polyphenol, ascorbic acid and total carotenoid contents in common fruits and vegetables. BJFT, 19, 89-94.

Quideau S, Deffieux D, Douat-Casassus C, Pouységu L (2011). Plant polyphenols: chemical properties, biological activities, and synthesis. Angew Chem Int Ed, 17, 586-21.

Ray PD, Huang BW, Tsuji Y (2012). Reactive oxygen species (ROS) homeostasis and redox regulation in cellular signaling. Cell Signal, 24, 981-90.

Reinaque PB, França EL, Scherer EF, et al (2012). Natural material adsorbed onto a polymer to enhance immune function. Drug Des Devel Ther, 6, 209-16.

Ribeiro AAL, Silva FH, Cotrim ACM, et al (2018). Herbal mixture adsorbed to polyethylene glycol microspheres induces apoptotic effects on breast cancer cells. Curr Drug Deliv, 14, 227-34.

Rufino MSM, Alves RE, Brito ES, et al (2010). Bioactive compounds and antioxidant capacities of 18 non-traditional tropical fruits from Brazil. Food Chem, 121, 996-02.

Sano EE, Rosa R, Brito JLS, Ferreira LG (2010). Land cover mapping of the tropical savanna region in Brazil. Environ Monit Assess, 166, 113-24

Scherer EF, Honorio-França AC, Hara CCP, et al (2011). Immunomodulatory effects of poly(ethylene glycol) microspheres adsorbed with nanofractions of Momordica charantia L. on diabetic human blood phagocytes. SAM, 3, 687-94

Scott EA, Nichols MD, Kuntz-Willits R, Elbert D (2010). Modular scaffolds assembled around living cells using poly(ethylene glycol) microspheres with macroporation via a non-cytotoxic porogen. Acta Biomater, 6, 29-38.

Siegel RL, Miller KD, Jemal A (2017). Cancer statistics. $C A$ Cancer J Clin, 0, 1-27.

Silva FH, Ribeiro AAL, Deluque AL, et al (2018). Effects of barium chloride adsorbed to polyethylene glycol (PEG) microspheres on co-culture of human blood mononuclear 
cell and breast cancer cell line (MCF-7). Immunopharmacol Immun, 40, 18-24.

Skrzydlewska E, Stankiewicz A, Sulkowska M, Sulkowski S, Kasacka I (2001). Antioxidant status and lipid peroxidation in colorectal cancer. J Toxicol Environ Health, 64, 213-22.

Sriram N, Kalayarasan S, Sudhandiran G (2008). Enhancement of antioxidant defense system by Epigallocatechin-3-gallate during bleomycin induced experimental pulmonary fibrosis. Biol Pharm Bull, 31, 1306-11.

Tran V, Benoîta JP, Venier-Juliennea MC (2011). Why and how to prepare biodegradable, monodispersed, polymeric microparticles in the field of pharmacy. Int J Pharm, 407, $1-11$.

\section{@ $(\mathbb{0} \otimes$}

This work is licensed under a Creative Commons AttributionNon Commercial 4.0 International License. 